\title{
浸透流の砂面擾乱の不安定性に及ぼす影響について EFECT OF INDUCED SEEPAGE FLOW ON PERMEABLE SAND BED INSTABILITY
}

\author{
村上正吾 ${ }^{1} \cdot$ 辻本哲郎 ${ }^{2}$ \\ Shogo MURAKAMI, Tetsuro TSUJIMOTO
}

${ }^{1}$ 正会員 工博 国立環境研究所 アジア自然共生研究グループ (テ305-8506茨城県つくば市小野川16-2)

${ }^{2}$ 正会員 工博 名古屋大学大学院工学研究科社会基盤工学専攻(

\begin{abstract}
We analyzed the effect of permeability of fluvial bed on the sand bed instability. The pressure gradient accompanied by the initial formation of sand waves inevitably produces the seepage flow through the fluvial bed. The induced seepage flow has significant effect on flow and sediment transport process. Bed load transport process is indirectly affected by the change of flow resistance, and is directly affected by seepage flow itself. Particularly, dislodgement of sand particles is severely influenced by the suction and injection. Hence, the induced seepage flow prompts or reduces the non-equilibrium bed load transport process and sand bed instability according to the permeability of bed materials particles and surface flow conditions. We applied stochastic sediment transport model in consideration of seepage effect, and revealed its effect on permeable sand bed instability by comparing sand bed instability without permeability with that with permeability.
\end{abstract}

Key Words : permeable fluvial bed, seepage flow, sand waves, sand bed instability, stochastic non-equilibrium sediment transport model

\section{1. まえがき}

水理構造物周辺や河床波が存在する流れ場では，流下 方向に圧力勾配が生じ，それに伴い浸透流（流下方向成 分と河床面を通過する流出入流速成分）が誘起され，結 局, 『河床面変形 $\rightarrow$ 誘起浸透流の形成 $\rightarrow$ 砂粒運動一の影

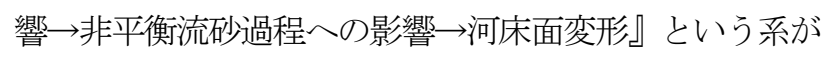
形成されることになる.この系については，古くから興

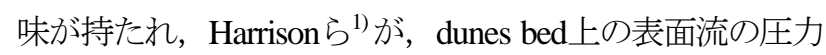
勾配と河床形状の位相差によって誘起される河床面を通 過する流出入流速（吹き出しと吸い込み）が流砂量に影 響を及ぼしduneの波形勾配を変化させると定性的な指摘 を初めて行った後, 1970年代前半には, 流出入流速の砂 粒の限界掃流力への影響がMartin ${ }^{2)}$, Oldemziel $ら^{3)}$, Watters $ら^{4)}$ により検討された. Willettsら $ら^{5)}$ は吹き出し場 での流砂量分布についての検討を行ったが，力学モデル

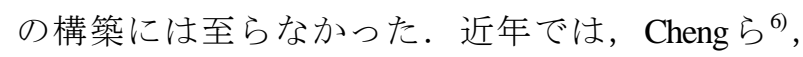
Francalanciら による砂料運動一の影響の水理学的検討に基づく力学モ デル構築への試みが続けられている．また，Chiewら ${ }^{8)}$ は, 一定強度に調節された一様な流出入流速場を持つ移動床 で河床波の実験を行い，この区間に流入進行する平衡河 床波の波形勾配と波高が吸い込みで減少, 吹き出しで増 加し, 再び平衡に至ることを実験的に示している. 一方,
河床波の不安定性については, Kennedy ${ }^{9}$ が線型不安定解 析の手法を持ち込んで以来, この手法に沿って行われた 研究のほとんどが境界面の条件としては不透水性を仮定 したもので，透水性河床の影響を検討した例は数少ない． Chu \& Gelhar ${ }^{10)}$ は, 透水性正弦波状河床上の表面流と河 床層内の浸透流のポテンシャルを誘導し, Kennedyの不 安定解析のフレームワークに適用したが, 結果的には Kennedyの理論で未知数となっていた流砂の遅れ距離を 河床波と水面の位相差で置き換えたもので，解析結果は Kennedyのものとは大差なく, 透水性境界面の効果を抽 出したとは言い難い。これは流砂の遅れ距離について合 理的な評価に至っていなかった事と，前述したように， 河床波面を通過する流出入流速が流砂過程に果たす役割 を的確に評価する流砂の力学モデルの研究の進展が十分 でなかった事にもよるものである.

本研究では, 砂面の不安定解析において不可欠な流砂 の非平衡性を十分に表現できる掃流砂のstochastic model を用いた中川・辻本 ${ }^{11,12)}$ による砂面不安定解析の枠組み を採用する.また，その構成要素であるpick-up rate step length，および流れ（特に抵抗則）に及ぼす流出入 流速の影響については著者ら ${ }^{13)}$ の結果を用いる. 解析的 な枠組みを統一し, 適用される流砂モデルの力学的構成 の同一性を保つことで, 誘起浸透流が砂面不安定に及ぼ 寸影響の検討が，初めて可能な状況に至ると考えられる. 


\section{2. 線形不安定解析の枠組み}

掃流砂による線形不安定解析の枠組みは, 次のように 要約できる. 移動床砂面の形状を次式のような正弦波の 微小擾乱 $\eta(x, t)$ とする.

$$
\eta(x, t)=-h_{0}+a(t) \cdot \sin \left\{\kappa\left(x-U_{b} t\right)\right\}
$$

ここで, $x$ : 流下方向軸, $t$ : 時間, $h_{0}$ : 非擾乱水深, $a$ : 砂面擾乱の振幅, $\kappa=2 \pi / L$ : 角波数, $L$ : 波長, $U_{b}$ : 擾乱 の伝播速度である. 下付添字 0 は, 非擾乱の值を示す。 線形近似の仮定の下では, 微小擾乱上の流れと流砂の特 性量は全て振幅・位相差の異なる同じ波数と波速をもつ 正弦波で表現される．例えば，掃流砂量 $q_{B}$ は次のように 表示される.

$$
q_{B}(x, t)=q_{B 0}\left[1+r_{B} a \cdot \sin \left\{\kappa\left(x-U_{b} t\right)-\phi_{B}\right\}\right]
$$

ここで, $\quad r_{B} a q_{B 0}, \phi_{B}$ : 掃流砂量の摂動の振幅と位相差で ある. 同様に，河床擾乱の発達・減衰を示寸時間変化率 は，次のように表示される。

$$
\partial \eta / \partial t=r_{y t} a \cdot \sin \left\{\kappa\left(x-U_{b} t\right)-\phi_{y t}\right\}
$$

式(2)と(3)は，次の掃流砂の連続式で関係付けられる。

$$
\partial \eta / \partial t=-1 /\left(1-\rho_{0}\right) \cdot \partial q_{B} / \partial x
$$

ここで， $\rho_{0}$ : 砂の間隙率である．式(2)，(3)，(4)より， 擾乱の時間変化率 $\partial \eta / \partial t$ 摂動の振幅と位相差 $r_{y t}, \phi_{y t}$ として次式が得られる.

$$
r_{y t}=\kappa r_{B} q_{B 0} /\left(1-\rho_{0}\right) ; \quad \phi_{y t}=(\pi / 2)+\phi_{\mathrm{B}}
$$

式(1)の時間微分と式(4)を等置すると次式が得られる.

$$
\begin{aligned}
& \frac{1}{a} \cdot \frac{\partial a}{\partial t}=r_{y t} \cos \phi_{y t}=-\frac{\kappa q_{B 0}}{1-\rho_{0}} r_{B} \sin \phi_{B} \\
& \kappa U_{b}=r_{y t} \sin \phi_{y t}=\frac{\kappa q_{B 0}}{1-\rho_{0}} r_{B} \cos \phi_{B}
\end{aligned}
$$

上式は砂面の擾乱の振幅増幅率と伝播速度・方向は位相 差 $\phi_{y}, \phi_{B}$ を調べれば良いことを示しており，線形解析の 枠組みでは， $\phi_{y}$ は次のような位相差の線形和として表現 されることが知られている12).

$$
\phi_{\mathrm{yt}}=\phi_{\tau}+\phi_{p \tau}+\phi_{\mathrm{B} p}+\phi_{\mathrm{yB}}=\phi_{\mathrm{B}}+\phi_{\mathrm{yB}}
$$

ここで， $\phi_{\tau}$ : 擾乱と底面せん断応力との位相差， $\phi_{p \tau}$ : 底 面せん断応力とpick-up rateとの位相差, $\phi_{B p}$ : 掃流砂量と pick-up rateとの位相差， $\phi_{k B}$ : 擾乱の時間変化率 $\partial \eta / \partial t$ と の位相差 $(=\pi / 2)$ である. 本研究では第1項 $\phi_{\tau}$ を透水性路床 上の流れモデルより，第2項 $\phi_{p r}$, 第3項 $\phi_{B p}$ を透水性路床 での流砂モデルより評価し，河床構成砂碩の透水性が擾 乱振幅増幅率に関わる各位相差に及ぼす影響を検討寸る。

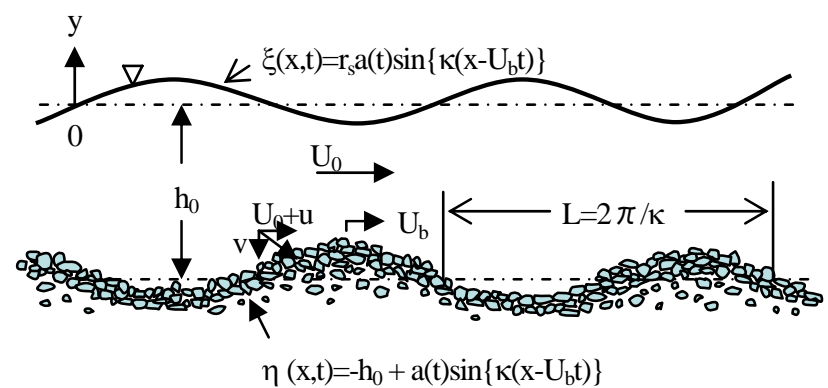

図-1＼cjkstart透水性河床波上の流孔の定義図

\section{3. 透水性正弦波状砂面上の流れ}

河床が透水性の高い砂礫より構成される波高の小さい 正弦波状砂面を仮定する時，水面波 $\xi(x, t)$ は次のよう に書ける.

$$
\xi(x, t)=r_{s}(t) a(t) \cdot \sin \left\{\kappa\left(x-U_{b} t\right)-\phi_{s}\right\}
$$

ここで, $r_{s} a$ : 水面波の振幅， $\phi_{s}$ : 砂面擾乱に対する水面 波の位相差である.

正弦波状擾乱河床上の表面流と層内浸透流の流れは Chu \& Gelher ${ }^{10}$ によってポテンシャル流理論を用いて扱 われ，一様部流速を $U_{0}$ とするとき，表面流と浸透流の摂 動流速に対する速度ポテンシャル $\phi_{1}, \phi_{2}$ は，

$$
\begin{aligned}
& \begin{aligned}
\phi_{1}(x, y, t) & =\frac{\cosh \kappa y+F r_{0}{ }^{2} \kappa h_{0} \sinh \kappa y}{F r_{0}{ }^{2} \kappa h_{0} \cosh \kappa h_{0}-\sinh \kappa h_{0}} U_{0} a \cos \delta \\
& \times \cos \left\{\kappa\left(x-U_{b} t\right)-\delta\right\}
\end{aligned} \\
& \begin{aligned}
\phi_{2}(x, y, t)= & \exp \left\{\kappa\left(y+h_{0}\right)\right\} U_{0} a \sin \delta \\
& \times \sin \left\{\kappa\left(x-U_{b} t\right)-\delta\right\}
\end{aligned}
\end{aligned}
$$

で与えられる，ここで， $\delta$ は河床形状に対する水面波の 位相差であり，透水性構成材の水理特性を長さの2乗の 次元を持つ透水係数 $K^{14)}$ によって表現すると，

$$
\tan \delta=\left(U_{0} \kappa K / v\right) \cdot F^{*} \equiv \operatorname{Re}_{s} \cdot F^{*}
$$

$F_{*}=\left(F r_{0}{ }^{2} \kappa h_{0} \tanh \kappa h_{0}-1\right) /\left(F r_{0}{ }^{2} \kappa h_{0}-\tanh \kappa h_{0}\right)$

と書ける. $\mathrm{Re}_{\mathrm{s}}$ が河床砂礫の透水性が流れに及ぼす影響 を表す項であり，表面流の水理量を用いると，次のよう に表示できる.

$\operatorname{Re}_{s}=U_{0} \kappa K=F r_{0} d_{*}(\sqrt{K} / d)^{2} \sqrt{h_{0} /(\sigma / \rho-1) d} \kappa h_{0}$

ここで, $F r_{0}$ : 非擾乱流のFroude数 $\left(=U_{0}\left(g h_{0}\right)^{1 / 2}\right), d_{*}$ : 無 次元粒径 $\left(=\left\{(\sigma / \rho-1) g d^{3}\right\}^{1 / 2} / \nu\right), d$ : 路床砂粒径, $K^{1 / 2} / d$ : 無 次元透水係数, $\sigma, \rho$ : 砂碩と水の密度, $v$ : 渦動粘性係 数である. 式(11)は, 位相差 $\delta$ は, Froude数, 河床の透 水性，流水抵抗， lower regimeとupper regimeの流れ区分 にも依存していることを示している.

河床面 $(y=-h)$ における表面流の流下方向，水深方向成 
段分であるU $(x, t)$ と $v(x, t)$ は，河床擾乱と関連付けて次 のように表示することができる.

$$
\begin{aligned}
& U(x, t)=U_{0}\left[1+r_{u} a \cdot \sin \left\{\kappa\left(x-U_{b} t\right)-\phi_{u}\right\}\right] \\
& v(x, t)=r_{v} U_{0} a \cdot \sin \left\{\kappa\left(x-U_{b} t\right)-\phi_{v}\right\}
\end{aligned}
$$

ここで, $r_{u} a U_{0}, r_{\downarrow} a U_{0}$ : 河床面 $(y=-h)$ での流下, 水深方 向速度の摂動分の振幅， $\phi_{u} ， \phi_{v}$ : 砂面擾乱に対するUお よびvの位相差である. 上式と速度ポテンシャル $\phi_{1}, \phi_{2} よ$ り決まる河床面浸透流の成分とを比較することより， $U(x, t)$ と $(x, t)$ の摂動の振幅および位相差は, それぞれ 次のように与えられる.

$$
\begin{aligned}
& r_{u} \sin \phi_{u}=\kappa F^{*} \sin \delta \cos \delta ; r_{u} \cos \phi_{u}=\kappa F^{*} \cos ^{2} \delta \\
& r_{v} \sin \phi_{v}=\kappa \sin ^{2} \delta ; r_{v} \cos \phi_{v}=\kappa \sin \delta \cos \delta
\end{aligned}
$$

水面波の振幅と位相差は，表面流のポテンシャルに対 する水表面での圧力条件と, 式(8)とを比較することで与 えられる. 寸なわち，砂面擾乱の振幅と水面波振幅 $r_{5} a$ の 比は，砂面の不安定性を示寸指標で次のように書ける ${ }^{11)}$

$$
\begin{gathered}
r_{s}=\left|s^{*}\right| ; \quad s^{*}=\frac{F r_{0}{ }^{2} k h_{0}}{F r_{0}{ }^{2} \kappa h_{0}-\tanh \kappa h_{0}} \cdot \frac{\cos \delta}{\cosh \kappa h_{0}} \\
\tan \phi_{s}=\tan \delta
\end{gathered}
$$

で, $\mathrm{s}^{*}>0$ のとき $\phi_{s}=\delta \fallingdotseq 0, \mathrm{~s}^{*}<0$ のき,$\phi_{\mathrm{s}}=\delta \fallingdotseq \pi$ となる.

\section{4. 砂面擾乱の不安定性に関わる位相差の評価}

\section{（1）流出入流速の砂面擾乱の不安定性解析に果たす意義}

高い透水性を有寸る河床の場合に誘起される浸透流, 特にその水深方向成分である流出入流速が砂粒の運動に 及ぼ寸影響は，直接的には水深方向の抗力成分の誘起に 伴う限界掃流力の変化, 間接的には抵抗則の変化を通じ ての底面せん断応力の変化として現れる. 従って透水性 砂面の不安定解析における流砂モデルには，この二つの 効果が組み入れられている必要がある. 著者ら ${ }^{13)}$ の検討 によると，流出入流速の影響は，砂粒の初期移動一の影 響が大きく, step lengthへの影響は限界掃流力付近の低 掃流力の場合に有意である。従って, dunesが形成され る水理条件下では, 移動特性量であるstep lengthへの影 響を無視し, 初期移動の特性量であるpick-up rate $p_{\mathrm{s}}$ の変 化に着目寸れば良いことになる。

流出入流速の存在する場での水流による無次元pick-up rate $p_{\mathrm{s}^{*}}$ 推定式は，次のように与えられる ${ }^{13)}$.

$$
p_{s^{*}}=F_{0} \frac{\Omega}{\Psi} \tau_{* n}\left(1-k_{2} \frac{\Psi}{\Omega} \cdot \frac{\tau_{* c n}}{\tau_{* n}}\right)^{3}
$$

ここで, $p_{s^{*}}=p_{s} /[d /\{(\sigma \rho-1) g\}]^{0.5}, F_{0}, k_{2}$ : 実験定数, $\tau_{*}$ :
無次元掃流力 $\left(=u_{*}^{2} /\{(\sigma \rho-1) g d\}, u_{*}\right.$ : 摩擦速度 $), \tau_{*}$ : 無 次元限界掃流力, $\Omega$ : 流出入流速による底面せん断応力 の変化指標， $\Psi$ : 限界掃流力の変化指標である. 下付添 え字听，流出入流速が無い場合の值を示す。

式(18)は, 不浸透路床の場合, pick-up rate $p_{s}$ はと対し て一意的に決まる $\left(\phi_{p \tau}=0\right)$ のに対し，透水性路床では，抵 抗則の変化を考慮した分布 $\tau\left(=\Omega \cdot \tau_{n}\right)$ だけでは， $p_{s}$ は決ま らず，流出入流速に起因寸る限界掃流力の変化分の位相 差 $\left(\phi_{p \tau} \neq 0\right)$ が存在すること示している.

このことを考慮し，直接・間接的効果を含めて実質的 にpick-up rateを規定する有効掃流力を $\tau_{*}=\Gamma_{\mathrm{e}} \cdot \tau_{* n}, \quad \Gamma_{\mathrm{e}}=\Omega / \Psi$, と定義すると，式(18)は

$$
p_{s^{*}}=F_{0}\left(\Gamma_{e} \tau_{* n}\right)\left\{1-\frac{k_{2} \cdot \tau_{* c n}}{\left(\Gamma_{e} \tau_{* n}\right)}\right\}^{3}=F_{0} \tau_{* e}\left(1-\frac{k_{2} \cdot \tau_{* c n}}{\tau_{* e}}\right)^{3}
$$

と書けることになる. こうした表示を行うと, pick-up rate $p_{s}$ は $\tau_{e}$ のみによって決まり, 形式上, 中川・辻本の 不安定解析の枠組みが，そのまま適用できることになる. このとき， $\tau_{e}$ の位相差 $\phi_{x}$ は $\phi_{\tau}+\phi_{p}$ で与えられる. 結局, 不透水性河床の場合と異なり, 底面せん断応力の位相差 に加えて $v_{0}$ にってもたらされるpick-up rateの位相差が 砂面擾乱の時間変化率の位相差 $\phi_{\mathrm{y}}$ に加算される形で, 透 水性の影響が砂面不安定に現れることになる.

\section{（2）微小な流出入流速の有効掃流力へ影響}

ここでは, 微小な流出入流速が存在する場での有効掃 流力に関わる指標 $\Gamma_{\mathrm{e}}(=\Omega / \Psi)$ の検討を行う．先ず，流出入 流速の存在による抵抗則（底面せん断応力）の変化率 $\Omega$ $\left(=\tau / \tau_{n}=\left(f / f_{n}\right)^{1 / 3}\right)$ は, 無次元流出入流速 $v_{0}^{+}\left(=v_{0} / u_{*_{n}}\right)$ に対 して次のように表される ${ }^{13)}$.

$\frac{v_{0}{ }^{+}}{4} \cdot\left\{\frac{8}{f_{n}}+\frac{1+\ln ^{2} \Omega}{\kappa_{0}{ }^{2}}\right\}+\frac{1}{\kappa_{0}} \cdot \frac{\ln \Omega}{\sqrt{\Omega}}=\sqrt{\frac{8}{f_{n}}} \cdot\left(\frac{1}{\Omega}-\sqrt{\Omega}-\frac{v_{0}{ }^{+}}{2 \kappa_{0}} \ln \Omega\right)$

ここで, $\kappa_{0}:$ Karman定数, $f, f_{n}$ : 流出入流速が有る場合 と無い場合の抵抗係数である. ただし，上式の誘導にお いては流出入流速が有る場合と無い場合のいずれの流れ も，単位幅流量およびエネルギ一勾配が同一の等流状態

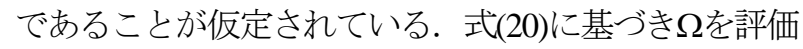
するためには繰り返し計算が必要である. そのため, こ こでは, 砂面の微小擾乱に対して誘起される流出入流速 $v_{0}$ が摩擦速度に対して十分に小さい場合を仮定して, 式(20)を $v_{0}{ }^{+}=0, \Omega=1$ の周りでTaylor展開し，その第1項の みを残した線形近似式を用いることとした。

$$
\Omega=1-\frac{1}{4} \cdot \frac{1 / \kappa_{0}^{2}+\phi_{0}^{2}}{1 / \kappa_{0}+3 \phi_{0} / 2} \cdot v_{0}{ }^{+} \equiv 1-\varepsilon \cdot v_{0}{ }^{+}
$$

ここで, $\phi_{0}:$ 流速係数 $\left(=U_{0} / u_{*}\right)$ である.

一方, 流出入流速による水深方向の抵力出現による限 界掃流力の変化指標 $\Psi \quad\left(=\tau_{c} / \tau_{c n}\right)$ は次式で与えられる ${ }^{13)}$. 


$$
\begin{aligned}
& \Psi=\left(1+k_{L} \mu_{f}\right) /\left\{1+\left(k_{L}+\varphi\right) \mu_{f}\right\}\left(A_{*} / A_{* n}\right)^{2} \\
& \varphi=\left(\varepsilon_{0}^{\prime} C_{D}^{\prime} / \varepsilon_{0} C_{D}\right) \cdot\left(\left|v_{0}{ }^{+}\right| v_{0}{ }^{+} / A_{*}{ }^{2}\right)
\end{aligned}
$$

ここで， $A_{*}=U_{d} / u_{*}, U_{d}$ : 砂粒に作用する代表流速, $k_{L}$ : 抗力 - 揚力比, $\mu_{f}$ : 静止摩擦係数, $\varepsilon_{0}, \varepsilon_{0}$ : 流出入流速 及び表面流に対する遮蔽係数, $C_{D}, C_{D}$ : 流出入流速及 び表面流に対する抗力係数である. 先ず, $\varphi$ の評価に当 たっては， $\varepsilon_{0}{ }^{\prime}=\varepsilon_{0}, C_{D}{ }^{\prime}=C_{D},\left(v_{0} / U_{d}\right)^{2}<<1$ ，を仮定し， $\varphi=0$ とした. 一方， $\Psi$ しいては表面流の流速分布を粗

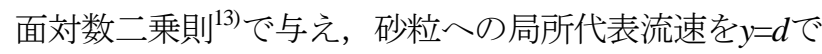
定義し， $A_{*}=\left(1+v_{0}{ }^{+} / 4\right) \cdot A_{*_{n}}$ とすることで, $v_{0}{ }^{+}=0$ 付近での 世を次のように近似した。

$$
\Psi=1-(1 / 2) \cdot v_{0}^{+}
$$

以上の $\Omega, \Psi の$ 検討結果を用いると， $v_{0}{ }^{+}<<1 の$ 場合の 有効掃流力に関わる指標 $\Gamma_{\mathrm{e}}$ は次のように表示できる.

$$
\Gamma_{e}=\Omega / \Psi=1-(\varepsilon-1 / 2) v_{0}^{+}
$$

図-2には，流出入流速による砂粒運動への影響指標 の $v_{0}{ }^{+}$に対する変化を示しており,$v_{0}{ }^{+}=0$ 近傍で式(24)が成 立していることが分かる。

\section{(3) 透水性路床上の底面せん断応力の評価}

$\Gamma_{\mathrm{e}}$ が式(24)で与えられる時， $\tau_{e}$ の評価に当たっては透 水擾乱路床 $\tau(x)$ の評価が必要となる。本研究では，中 川・辻本の不安定解析の枠組みを採用することで，砂面 擾乱がどのように河床面の透水性の影響を受けているか を明らかにすることを目的としていることより，底面せ ん断応力を評価する流れのモデルとしては，ポテンシャ ル流理論で評価される局所流速に空間的加速効果を考慮 する方法を用いた ${ }^{11)}$. この時，底面せん断応力 $\tau(x)$ は次 のように局所流速Uと水深変化 $\partial h / \partial x$ と関係づけられる

$$
\tau(x)=\beta \rho U^{2}\left\{1-\left(\gamma / F r_{0}^{2}\right)(\partial h / \partial x)\right\}
$$

$\beta, \gamma:$ 経験定数である. 式(13)を上式に代入し，

$$
\tau(x, t)=\tau_{0}\left[1+r_{\tau} a \cdot \sin \left\{\kappa\left(x-U_{b} t\right)-\phi_{p \tau}\right\}\right]
$$

と比較すると， $\tau(x)$ の振幅 $\mathrm{r}_{\tau}$ と位相差 $\phi_{\tau}$ は次のように評 価され， $\delta=0$ の場合は不透水性河床での中川・辻本の結 果に一致する ${ }^{11,12)}$. ただし, $\tau_{0}=\beta \rho U_{0}^{2}{ }^{2}$ である.

$$
\begin{gathered}
r_{\tau} \sin \phi_{\tau}=\kappa F^{*} \sin \delta \cos \delta+\gamma \kappa\left(s^{*}-1\right) / F r_{0}{ }^{2} \\
r_{\tau} \cos \phi_{\tau}=\kappa F^{*} \cos ^{2} \delta-\gamma \kappa r_{s} \sin \phi_{s} / F r_{0}{ }^{2}
\end{gathered}
$$

$\phi_{p \tau}$ の決定は，式(24)に式(26)を代入し，線形化の後，

$$
p_{s}(x, t)=p_{s 0}\left[1+r_{p} a \cdot \sin \left\{\kappa\left(x-U_{b} t\right)-\phi_{p}\right\}\right]
$$

と比較することで, 最終的にpick-up rate $p_{s}$ の摂動分の振 幅 $r_{p}$ とその位相差 $\phi_{p}$ が次式のようにまとめられる.

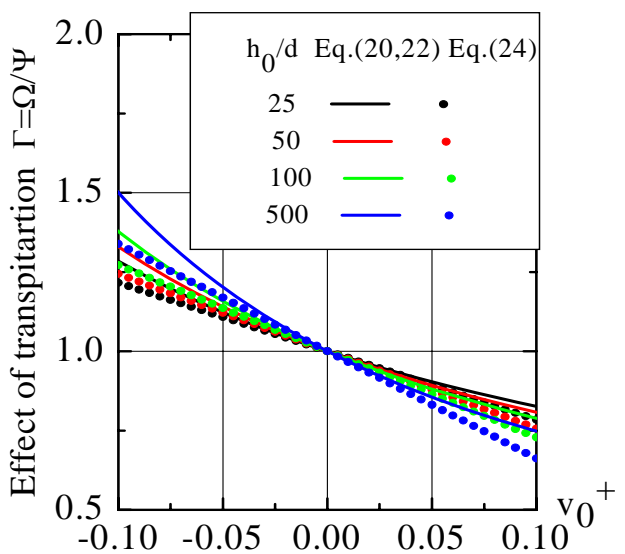

図-2 流出入流速の有効掃流力指標への影響

$r_{p} \sin \phi_{p}=\frac{1-3 \omega^{2}+2 \omega^{3}}{(1-\omega)^{3}} \cdot\left(r_{\tau} \sin \phi_{\tau}-\varepsilon \phi_{0} r_{v} \sin \phi_{v}\right)$

$r_{p} \cos \phi_{p}=\frac{1-3 \omega^{2}+2 \omega^{3}}{(1-\omega)^{3}} \cdot\left(r_{\tau} \cos \phi_{\tau}-\varepsilon \phi_{0} \cos \phi_{v}\right)$

ここで， $\omega=k_{2} \tau_{c n} / \tau_{n}$ である.

不安定性の指標である $\phi_{y t}$ の評価のためには，さらに流 砂モデルから有効掃流力と流砂量の遅れが必要とされる。 平均step length $\Lambda$ は流出入流速によって大きく変化しな いことが知られており，不透水砂面における非平衡掃流 砂モデルの検討結果を用いると， $q_{B}$ と $p_{s}$ との位相差 $\phi_{B p}$ (遅れ距離 $\kappa \delta_{\mathrm{Bp}}$ ) は次のように与えられる ${ }^{11,12)}$.

$$
\tan \left(\kappa \delta_{B p}\right)=\kappa \Lambda=\kappa h_{0} \cdot(\Lambda / d) \cdot\left(d / h_{0}\right)
$$

以上の検討により，透水性砂面の不安定性を指標であ る $\phi_{y t}$ を構成する全ての位相差 $\phi_{\tau}, \phi_{p \tau}, \phi_{p}, \phi_{B p}, \phi_{y B}$ が水 理量，砂粒特性に対して求められたことになる.

\section{4. 透水性の高い路床での不安定解析の計算結果}

通常の不安定解析では，結果を $F r_{0} \sim \kappa h_{0}$ 平面上に表 示することより，計算の便宜上，ここでは，通水結果と しての表面流の水理特性量であるFroude数 $F r_{0}$, およひ砂 粒Reynolds数Re* $(=u * d / v)$ を所与条件とし, 相対水深 $h_{0} / d$ を 対数則型の抵抗則 $\ln \left(11.0 \mathrm{~h}_{0} / \mathrm{d}\right) / \kappa_{0}=\left(\mathrm{Fr}_{0} \mathrm{~d}_{*} / \mathrm{Re}_{*}\right) \cdot\left(\mathrm{h}_{0} / \mathrm{d}\right)^{1 / 2}$ を仮 定することで評価した．計算に当たっては，Re* $=40$, $\Lambda / d=100$ とした. 路床砂礫径は， $d=0.02,0.05,0.15(\mathrm{~cm})$ と変化させた。 また，無次元透水係数は $\mathrm{k}_{*}=\mathrm{K}^{1 / 2} / \mathrm{d}=\alpha \cdot \mathrm{k}_{\mathrm{m}}$ と表示でき, $\alpha=0.5 \sim 2, \mathrm{k}_{\mathrm{m}}=0.028$ あることが実験的に 知られており ${ }^{15)}$, 計算では平均值として $\alpha=1$ とした. こ の水理条件範囲での最大誘起流出入流速は, $\mathrm{d}=0.02 \mathrm{~cm}$ は擾乱流速 $U_{0} の 0.1 \%, d=0.15 \mathrm{~cm}$ では3\%程度であった。 


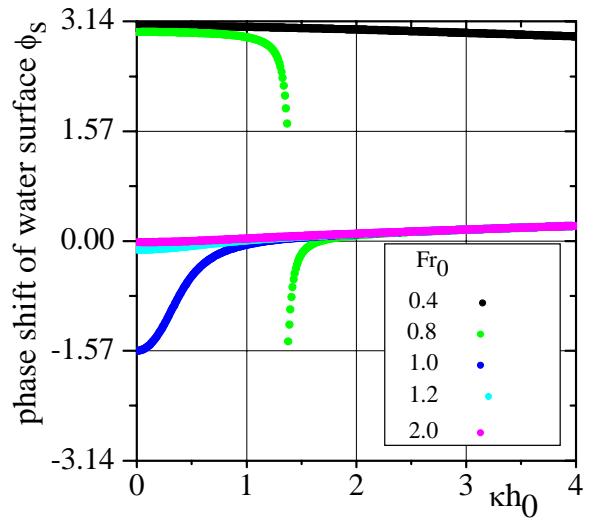

図-3 河床形状に対する水面形の位相差 $\phi_{s}$

図-3は, Froude数 $F r_{0}$ をパラメータに，無次元波数 $\mathrm{h} \mathrm{h}_{0}$ に対して河床擾乱に対する水面の位相差恃を示したもの である. lower regimeにおいては不透水性河床での位相 差 $\phi_{s}=\pi$ よりやや小さい傾向を示すのに対し, upper regime では，不透水性河床での位相差 $\phi_{s}=0$ が，低波数でやや位 相が遅れるのに対し，高波数側で $\phi_{s}>0$ となる.

図-4は, 不透水性河床の場合の底面せん断応力の位相 差 $\phi_{\tau}$ を示したもので, 中川・辻本の結果 ${ }^{11,12)}$ と同じであ り, この時には, 底面せん断応力とpick-up rateとの位相

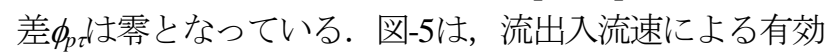
掃流力 $\tau_{e}$ の河床面形状に対する位相差 $\phi_{\text {« }}$ を示しており, 図-4と図-5の差が，、 位相差分を示している. 図-6は, 河床高の時間変化率 $\phi_{y t}$ をFr $r_{0}$ をパラメータに， $h_{0}$ に対して示してあり， $\phi_{y t}$ の象 限に応じて砂面擾乱の安定性と伝播方向が判断できる. 図-7は, $F r_{0} \sim s h_{0}$ 平面上で, 砂面擾乱の安定・不安定領 域を示したものである. 砂礫径の大小による透水性の効 果を見るため，これまでの実験結果 ${ }^{16)}$ を0.0088〜 0.025(cm)， $0.035 \sim 0.055(\mathrm{~cm}), \quad 0.1 \sim 0.23(\mathrm{~cm})$ のつの粒径 範囲に分け, 透水性が無い場合 $\left(\mathrm{k}_{*}=0\right)$ および砂礫径を $d=0.02,0.05,0.15(\mathrm{~cm})$ で代表させた透水性砂面でのモデ 儿計算結果と比較した. 灰色の領域が不安定性領域であ る. $\mathrm{k}_{*}=0$ とd=0.02(cm)の場合は, 低波数側のantiduneで領 域判定に差異が有るが，ほぼ同様の不安定領域を示して いる. antiduneでの安定化については，この領域で相対 水深がかなり小さくなることの各位相差に及ぼす影響を 検討する必要があると考えられる，透水性が大きくなる $d=0.15(\mathrm{~cm})$ の場合，低波数側 $\left(\kappa h_{0}=2\right.$ 以下)で, $F r_{0}=0.5 \sim 0.8$ の範囲で, dunesが安定化する傾向が認められた。この 近傍に $d=0.2(\mathrm{~cm})$ 程度の粗砂での実験結果はあるものの, 計算の検証には至っていない. 透水性の影響伝播方向に ついては，粒径，透水性に関わらず， dunesはすべて下 流方向にantidunesのほとんどは上流方向に伝播するとい う従来の解析と同じ結果がモデル計算では得られている.

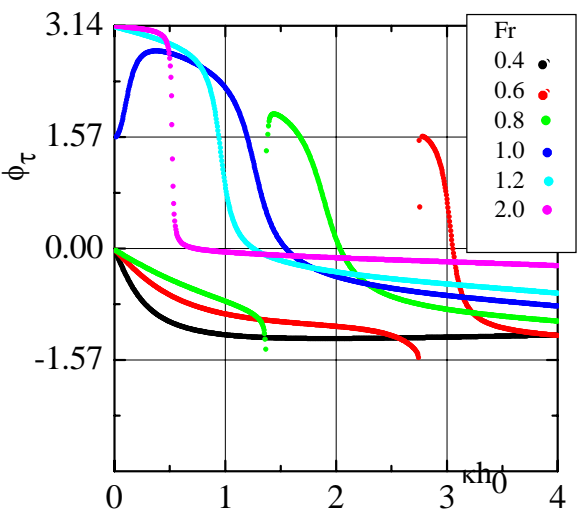

図-4 河床形状に対する底面せん断応力の位相差 $\phi_{\tau}$ (不透水性河床 : $\phi_{p p}=0$ )

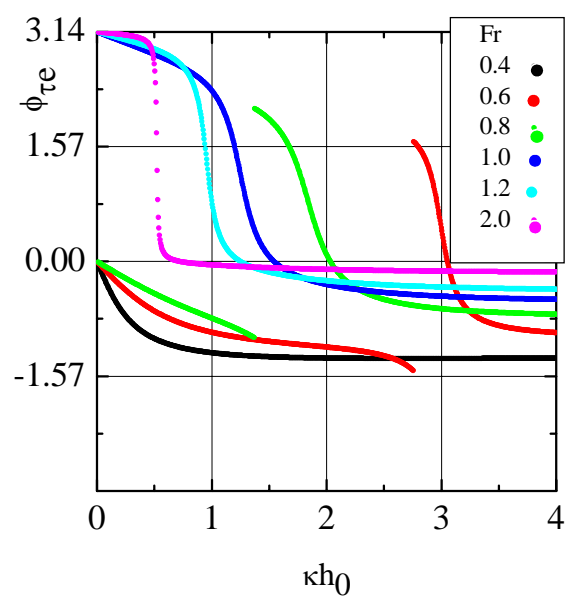

図-5 河床形状に対する有効底面せん断応力の位相差 $\phi_{\pi e}$ (透水性河床 : pick-up rate $の$ 位相差 $\phi_{\pi e}=\phi_{\tau}+\phi_{p \tau}$ )

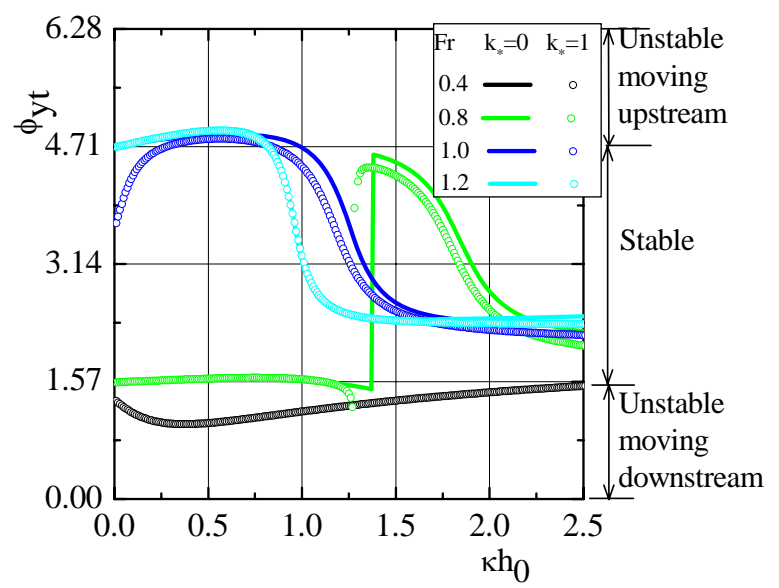

図-6 河床形状に対する河床高時間変化率の位相差 $\phi_{y t}$ (河床透水性の効果 : pick-up rate $の$ 位相差 $\phi_{p p} \neq 0$ ) 

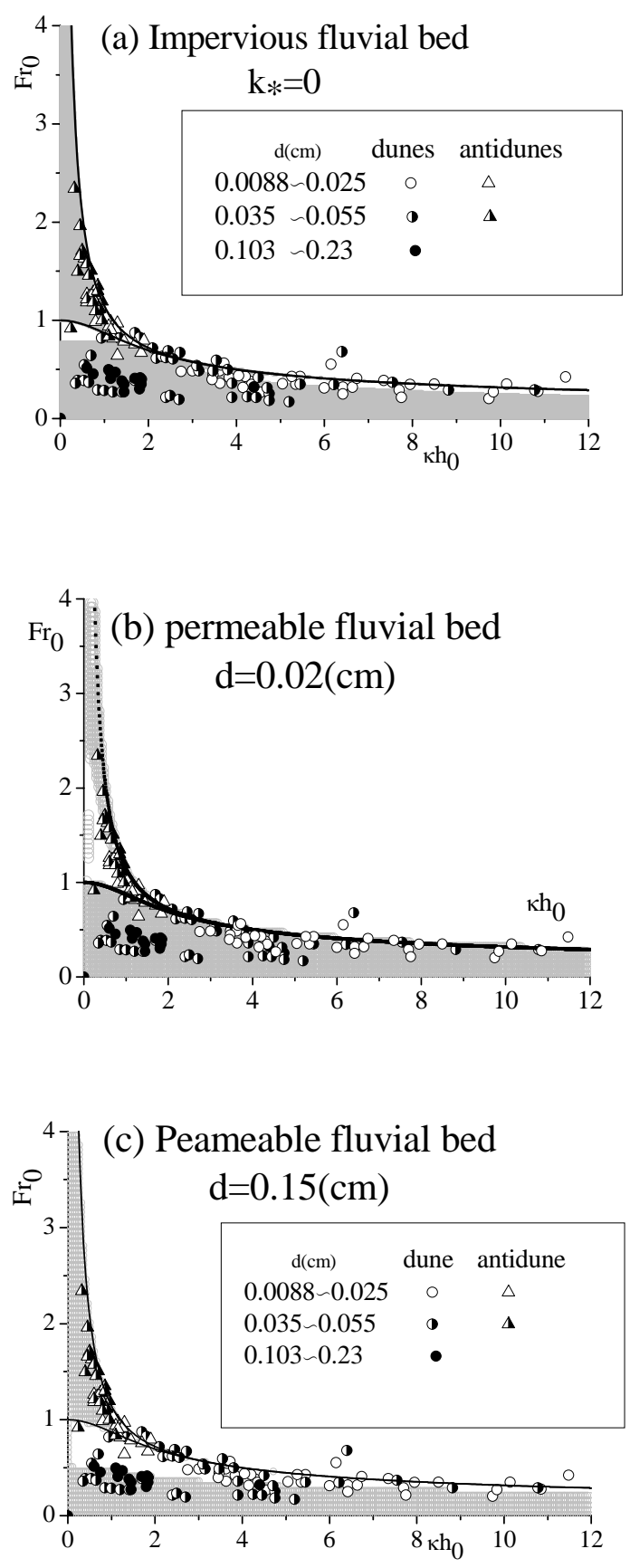

図-7 透水性砂面の不安定解析の計算結果
(路床構成砂砂径の変化の影響)

\section{6. あとがき}

本研究では，中川・辻本の砂面不安定解析の枠組みに 流出入流速の影響を考慮した流砂モデルを組み込んだ透 水性河床擾乱の不安定解析の基本的なモデルを提示し, 河床波の存在に伴う流れの圧力勾配によって誘起される 流出入流速の不安定解析における役割について検討した. 提案したモデルを用いた計算結果は，路床構成砂礫の透 水性により不透水性路床の場合と比較して不安定領域が
変化することを示していたが，粒径，路床透水性の変化 に伴う不安定領域の変化の妥当性を検証するためには, 今後さらに実験データの収集が必要であると考えられた.

\section{参考文献}

1) Harrison, S. S. and Clayton, L.: Effect of ground water seepage of fluvial processes, Geol. Soc. Amer. Bull. , No.811, PP.1217-1225, 1968.

2) Martin, C. S.: Effect of a porous sand bed on incipient motion, Water Resour. Res., Vol.6, No.4, pp.1162-1174, 1970.

3) Oldenziel, D. M. and Blink, W. E.: Influence of suction and blowing on entrainment of sand bed, J. Hydraul. Div., Proc. ASCE, Vol. 100, HY7, pp. 935-948, 1974.

4) Watters, G. Z. and Rao, M. V.: Hydrodynamic effects of seepage on bed particles, J. Hydraul. Div., Proc. ASCE, Vol. 97, HY3, pp.421439, 1971.

5) Willetts, B. B. and Dorossos, M. E.: Local erosion caused by rapid forced infiltration, J. Hydraul. Div., Proc. ASCE, Vol. 101, HY12, pp.1477-1488, 1975.

6) Cheng, N. S. and Chiew, Y. M.: Incipient sediment motion with seepage, Journal of Hydraulic Research, 37(5), 665-681, 1999.

7) S. Francalanci, G. Parker and L. Solari: Bedload transport in the case of seepage flow, Proc. of the international conference on fluvial hydraulics, River Flow 2006, Vol.2, pp.1569-1576, 2006.

8) Chiew, Y. M. and Lu., Y. : Seepage effect on dune geometry, Civil Engineering Research, Nanyang Technological University, No.17, pp.116-118, 2004.

9) Kennedy: The mechanics of dunes and antidunes in erodible bed channel, J. Fluid Mech., 16, pp.521-544, 1963.

10) Chu, Y. and L. W. Gelher : Turbulent pipe flow with granular permeable boundaries, Report, Ralph Parsons Laboratory, M. I. T., No.148, 1972.

11) Nakagawa \& Tsujimoto : Sand bed instability due to bed load motion, J. Hydraul. Div., ASCE, 106-HY12, pp.2029-2051, 1980.

12) 中川博次・辻本哲郎 : 移動床砂面の不安定要因としての遅 れ距離・位相差, 土木学会論文報告集, 第305号, pp.139142, 1981.

13) 村上正吾・辻本哲郎・中川博次 : 掃流過程における河床面 を通しての流出入流速の影響, 土木学会論文集, 第423号/ II-14, pp.53-62, 1990.

14) Ward, J. C.: Turbulent flows in porous media, Jour. Hydraul. Engrg., ASCE, Vol.90, HY5, pp.1-12, 1964.

15) 中川博次 : 明石海峡大橋主塔基礎の洗掘防止工法に関する 研究 : 財団法人防災研究協会 検討報告書, 1987 .

16) Yalin,M., S.: Mechanics of sediment transport, Ch.7, Sand waves, pp.216, $2^{\text {nd }}$ Edition, 1977.

(2006. 9. 30受付) 